Prediction of macro- and microelements content in Croatian common bean landraces (Phaseolus vulgaris L.) by NIR spectroscopy

Procjena količine makro- i mikroelemenata u hrvatskim tradicijskim kultivarima graha (Phaseolus vulgaris L.) korištenjem spektroskopije u bliskome infracrvenom području (NIRS)

Vranić, M., Petek, M., Bošnjak, K., Lazarević, B., Carović-Stanko, K.

Poljoprivreda/Agriculture

ISSN: $1848-8080$ (Online)

ISSN: $1330-7142$ (Print)

http://dx.doi.org/10.18047/poljo.25.1.7

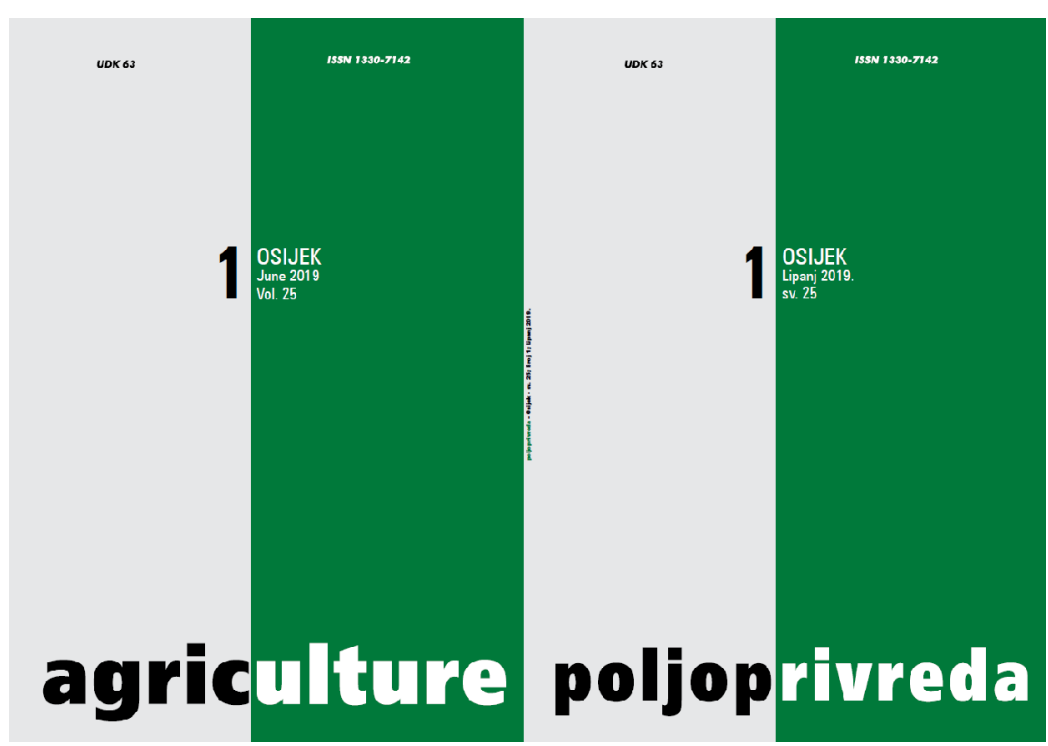

Fakultet agrobiotehničkih znanosti Osijek, Poljoprivredni institut Osijek

Faculty of Agrobiotechnical Sciences Osijek, Agricultural Institute Osijek 
ISSN $1330-7142$

$U D K=635.652: 577.118: 001.891$

DOI: $10.18047 /$ poljo.25.1.7

\title{
PREDICTION OF MACRO- AND MICROELEMENTS CONTENT IN CROATIAN COMMON BEAN LANDRACES (Phaseolus vulgaris L.) BY NIR SPECTROSCOPY
}

Vranić, M. ${ }^{(1)}$, Petek, M. ${ }^{(2)}$,Bošnjak, K. ${ }^{(1)}$, Lazarević, B. ${ }^{(2,4)}$, Carović-Stanko, K. ${ }^{(3,4)}$

Original scientific paper

Izvorni znanstveni članak

\begin{abstract}
SUMMARY
In this study, near-infrared spectroscopy (NIRS) was used to predict the contents of essential macro- and microelements in common bean (Phaseolus vulgaris L.) accessions of most widespread Croatian landraces. Total of 175 samples were used for the model development by modified partial least square (MPLS), principal component regression (PCR) and partial least square (PLS) techniques. Based on the coeffcients of determination $\left(R^{2}\right)$, standard error of calibration (SEC) and error of prediction (SEP) the models developed were (i) nearly applicable for nitrogen (N) $(0.89,0.12$ and 0.45 respectively), (ii) poor for iron (Fe), cinc (Zn), potassium oxide $\left(\mathrm{K}_{2} \mathrm{O}\right)$ and potassium (K), (iii) usable for phosphorus pentoxide $\left(\mathrm{P}_{2} \mathrm{O}_{5}\right)$, phosphorus (P), phytic acid (PA) and manganese (Mn). The MPLS regression statistics suggested the most accurate models developed comparing with PLS and PCR. It was concluded that a wider set of common bean samples needs to be used for macro- and microelements prediction by NIRS.
\end{abstract}

Key words: common bean, macronutrients, micronutrients, minerals, NIRS

\section{INTRODUCTION}

Common bean (Phaseolus vulgaris L.) is grown all over the world. However, before domestication, the wild type of common bean has already been divided into two basic groups with regard to geographic origin - the Andean and Central American group (Petry et al., 2015). It is the most important legume for human nutrition and a valuable source of protein, fiber, vitamins and minerals (Suárez-Martínez et al., 2016). Dried beans worldwide in 2017 were harvested on 36.5 million hectares with production of 31.4 million $t$ (FAO, 2019) proving its great importance in human nutrition. Beans are known to be used for treating different kind of human diseases and conditions such as diabetes, diuretic, burns, acne, cardiac, bladder, carminative, itchy, and rheumatism (Ganesan and Xu, 2017; Lešić et al., 2016).

Near-infrared spectroscopy (NIRS) has been widely adopted for low-cost, non-destructive analysis of fruits, vegetables and grains (Nicolai et al., 2007 Osborne et al., 2006; Vranić et al., 2012). NIRS has been widely applied to evaluate the internal quality of common bean with the primary advantage that the technique requires minimum sample preparation (Haughey et al., 2013; Kaliramesh et al., 2013). However, to the best of our knowledge, there are no studies reported on the development of NIRS calibration models for predicting the mineral composition of common bean samples.

(1) Prof. Marina Vranić, Ph.D., Assoc. Prof. Krešimir Bošnjak, Ph.D. University of Zagreb, Faculty of Agriculture, Department of Field Crops, Forage and Grasses, Grassland Research Centre, Svetošimunska cesta 25, HR-10000 Zagreb, Croatia, (2) Assist. Prof. Marko Petek, Ph.D. (mpetek@ agr.hr), Assist. Prof. Boris Lazarević, Ph.D. - University of Zagreb, Faculty of Agriculture, Department of Plant Nutrition, Svetošimunska cesta 25, HR-10000 Zagreb, Croatia, (3) Assoc. Prof. Klaudija Carović-Stanko, Ph.D. - University of Zagreb, Faculty of Agriculture, Department of Seed Science and Technology, Svetošimunska cesta 25, HR-10000 Zagreb, Croatia, (4) Centre of Excellence for Biodiversity and Molecular Plant Breeding (CroPBioDiv), Zagreb, Croatia 
The hypothesis of this research is that NIR spectroscopy is a powerful toll for quick measurement of macro and microelements in common bean samples. The objective of this work is to evaluate NIR spectroscopy techniques for prediction of the macro and microelements in common bean samples.

\section{MATERIAL AND METHODS}

\section{Field trial and plant sampling}

The research was carried out during growing season 2014 on 175 common bean accessions. Seed samples of the studied accessions were collected directly from producers all over Croatia. Accessions were grown under equal conditions in unreplicated field trial on the experimental field of the Department of Seed Science and Technology, Faculty of Agriculture, University of

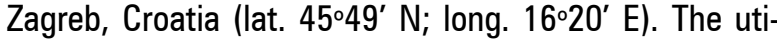
lized common bean growing technology followed the normal working procedure for common bean production. Harvested common bean seeds from each field plot were collected and homogenized samples created.

\section{Chemical analysis}

Common bean seeds samples (dried at $70^{\circ} \mathrm{C}$ to a constant weight) were divided into three subsamples and analysed. Dried common bean samples were ground to pass $1 \mathrm{~mm}$ screen using laboratory mill. Nitrogen was determined using the Kjeldahl method (HRN ISO 11261:2004). Nitrogen content is converted to crude protein (CP) by multiplying by 6.25 (Vajić, 1964). After digestion with concentrated $\mathrm{HNO}_{3}$ (MILESTONE 1200 Mega Microwave Digester), phosphorus content was determined using a spectrophotometer (EVOLUTION 60S UV-VISIBLE), potassium by a flame photometer (JANWEY PFP 7), while calcium, magnesium, iron, zinc and manganese were analysed by an atomic absorption spectrophotometer (AAS SOLAR THERMO SCIENTIFIC) (AOAC, 1995).

Phytic acid (PA) was determined using the standard assay procedure of K-PHYT (Megazyme ${ }^{\odot}$ 2017).

\section{Spectral data collection}

After having common bean seed ground, the samples were placed in a drier at a temperature of $105^{\circ} \mathrm{C}$ for at least 3 hours and then cooled in a desiccator. The cooled samples were scanned in a NIR 6500 spectrometer (Foss-NIR system, Sweden) equipped with the sample transport module. Each sample was placed in a rectangular cuvette for sample scanning $(5$ by $6.5 \mathrm{~cm}$ in dimension) and sealed with a cardboard top to make sure that the sample adhered well to the cuvette's quartz glass.

Each sample was scanned separately three times. The samples were randomly divided into three sets using WinlSI III software: (i) calibration set; (ii) validation set and (iii) repeatability file.

The spectral values of each scan were obtained using ISI SCAN software (Version 1.0) developed by
Infrasoft International, Port Matilda, PA, USA. When scanned, the samples were exposed to 32 scans in reflectance mode ( $\mathrm{R}$ mode: $\mathrm{PbS}$ detector) in the wave length range from 1100 to $2498 \mathrm{~nm}$. Spectral data was read at intervals of $2 \mathrm{~nm}$ and each scan allowed the collection of 700 items of data.

Once scanned, the samples were exported from ISI SCAN software into WinISI III software (Version 1.5) for further processing. At first, the mean spectral value was calculated for each sample. Two samples, whose global deviation (global $\mathrm{H}$ ) was higher than 3 , were excluded from further consideration as outliers (Kirk, 1995).

\section{Spectral data analysis}

The calibration model was generated using WinISI III software developed by Foss, NIRSystems (Silver Spring, MD). For calibration purposes, different mathematical treatments of collected spectral data were tested (differentiation order, subtraction gap, smoothing interval), with or without applying Standard Normal Variance (SNV) and Detrend for Scatter Correction. Each spectrum was SNV corrected to achieve standard deviation 1.0, in order to reduce the impact of particle size and square spectral inequalities (ISI, 1999).

The collected spectral data were used for producing predictive calibration model that describe the relationship between spectral data and chemical composition for the following chemical constituents: $\mathrm{N}, \mathrm{P}_{2} \mathrm{O}_{5}, \mathrm{P}, \mathrm{K}_{2} \mathrm{O}$, $\mathrm{K}, \mathrm{Ca}, \mathrm{Mg}$, phytic acid (PA), Fe, $\mathrm{Zn}$ and $\mathrm{Mn}$. Three standard chemometric methods were applied to optimize calibrations: (i) modified partial least square (MPLS), (ii) principal component regression (PCR) and (iii) partial least square (PLS).

The study used cross validation as described by Davies and Williams (1996). Validation errors were indicated as standard errors of cross validation (SECV) (Shenk and Westerhaus, 1995). The quality of the calibration is evaluated by the validation of the equation performed by comparing the values predicted by NIR spectroscopy with the reference values of samples.

The choice of the best equation, the capacity to assess the developed model, and recognising the unacceptable spectrum, were done as previously described by Vranić et al. (2016).

\section{RESULTS AND DISCUSSION}

Chemical composition of common bean samples used in the experiment are presented in Table 1. The samples used varied in composition as confirmed by the range and the coefficient of variation (CV) with the greatest $\mathrm{CV}$ observed for $\mathrm{K}_{2} \mathrm{O}$ and $\mathrm{K}$. The recognised variability might be suitable for developing NIR calibrations.

Figure 1 shows the average spectral data of three scans per sample used in the experiment. The two samples have a different progress in a curve form thus were found as outliers $(\mathrm{H}>3)$ and excluded from further processing. According to the spectra the rest of the samples (173) belong to the same calibration set. 
Table 1. The chemical composition of samples used in the experiment $(n=175)$.

Tablica 1. Kemijski sastav uzoraka korištenih u pokusu $(n=175)$.

\begin{tabular}{|c|c|c|c|c|c|c|c|c|c|c|c|}
\hline $\begin{array}{l}\text { Chem. } \\
\text { Elem. }\end{array}$ & $\mathrm{N}$ & $\mathrm{P}_{2} \mathrm{O}_{5}$ & $P$ & $\mathrm{~K}_{2} \mathrm{O}$ & K & $\mathrm{Ca}$ & $\mathrm{Mg}$ & PA & $\mathrm{Fe}$ & $\mathrm{Zn}$ & $\mathrm{Mn}$ \\
\hline $\begin{array}{l}\text { Units } \\
\text { Jedinice }\end{array}$ & \multicolumn{8}{|c|}{$\begin{array}{c}\% \text { in DM / } \\
\% \text { u } S T\end{array}$} & \multicolumn{3}{|c|}{$\begin{array}{c}\mathrm{mg} \mathrm{kg}^{-1} \mathrm{DM} \\
\mathrm{mg} \mathrm{kg}^{-1} S T\end{array}$} \\
\hline $\begin{array}{l}\text { Mean } \\
\text { Prosjek }\end{array}$ & 3.36 & 1.19 & 0.53 & 2.39 & 1.98 & 0.37 & 0.18 & 0.67 & 71.74 & 26.86 & 16.37 \\
\hline Min & 2.67 & 0.95 & 0.41 & 1.42 & 1.17 & 0.18 & 0.10 & 0.25 & 37.31 & 18.33 & 11.62 \\
\hline Max & 4.45 & 1.65 & 0.72 & 19.4 & 16.09 & 1.69 & 0.26 & 1.07 & 127.21 & 48.73 & 25.17 \\
\hline SE & 0.03 & 0.01 & 0.004 & 0.24 & 0.20 & 0.01 & 0.002 & 0.01 & 0.81 & 0.31 & 0.19 \\
\hline SD & 0.36 & 0.14 & 0.06 & 3.27 & 2.71 & 0.15 & 0.02 & 0.15 & 10.73 & 4.14 & 2.54 \\
\hline CV \% & 10.7 & 11.9 & 11.8 & 136.8 & 136.8 & 42.8 & 14.8 & 22.9 & 14.9 & 15.4 & 15.5 \\
\hline
\end{tabular}

Chem. - chemical parameter; PA - phytic acid; DM - dry matter; Mean - mean value; Max - maximum value; Min - minimum value; SE - standard error; SD - standard deviation; CV - variation coefficient

Elem. - kemijski parametar; PA - fitinska kiselina; ST - suha tvar; Prosjek - prosječna vrijednost; Max - najveća vrijednost; Min - najmanja vrijednost; SE - standardna greška; SD - standardna devijacija; CV - varijacijski koeficijent

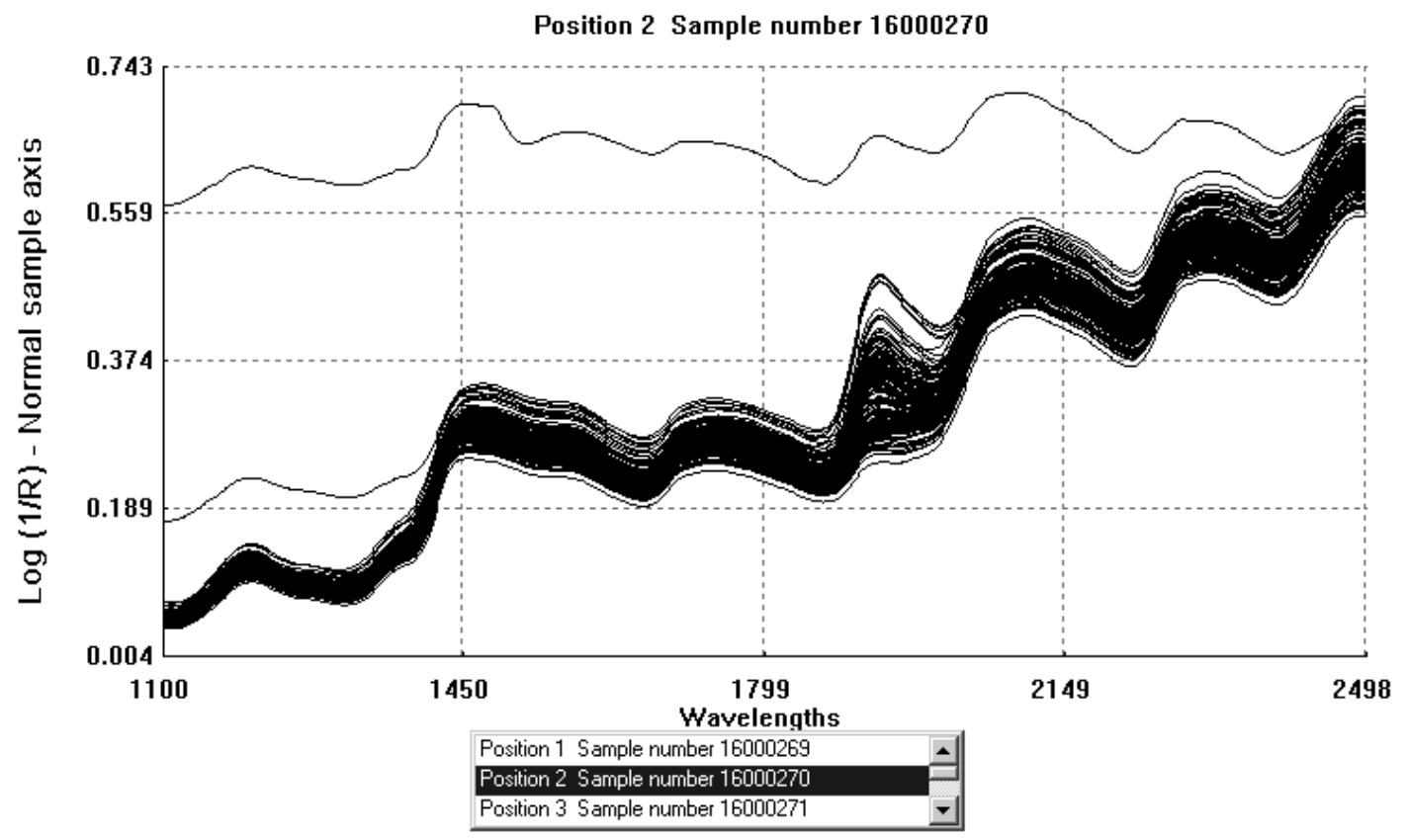

Figure 1. The average spectral data of three scans per sample used in the experiment $(n=175)$.

Slika 1. Prosječni spektralni podatci 3 skeniranja po uzorku korištenim u istraživanju $(n=175)$.

Statistics of models developed for macroelements in common bean samples by MPLS, PLS and PCR method are presented in Table 2.

The most important of this statistics are the standard error of calibration (SEC), standard deviation (SD), coefficient of correlation (RSO), standard error of cross validation (SECV) and standard error of prediction (SEP) calculated for the different macro and microelements used in calibration and validation set. These values are crucial in grading model reliability, thus, making decisions on further application.

Validation statistics of the developed calibration models ranging in coeffcients of determination $\left(R^{2}\right)$ from 0.04 for $\mathrm{K}_{2} \mathrm{O}$ and Fe to 0.894 for $\mathrm{N}$. 
Table 2. Prediction of macroelements in common bean samples by modified partial least squares (MPLS) regression, partial least square (PLS) regression and principal component regression (PCR) analysis.

Tablica 2. Procjena količine makroelemenata u uzorcima graha korištenjem modificirane metode najmanjih kvadrata (MPLS), metode najmanjih kvadrata (PLS) i metode regresije osnovne komponente (PCR).

\begin{tabular}{|c|c|c|c|c|c|c|c|c|c|c|}
\hline $\begin{array}{l}\text { Chem. } \\
\text { Elem. }\end{array}$ & $\begin{array}{l}\text { Method } \\
\text { Metoda }\end{array}$ & $n$ & $\begin{array}{c}\text { Mean } \\
\% \text { in DM } \\
\text { Prosjek } \\
\% \text { u ST }\end{array}$ & SD & $\begin{array}{c}\text { Min } \\
\% \text { in DM } \\
\text { Min } \\
\% \text { u ST }\end{array}$ & $\begin{array}{c}\text { Max } \\
\% \text { in DM } \\
\text { Max } \\
\% \text { u ST }\end{array}$ & SEC & RSO & SECV & SEP \\
\hline \multirow{3}{*}{$\mathrm{N}$} & MPLS & 93 & \multirow[t]{3}{*}{3.34} & 0.37 & 2.26 & 4.43 & 0.117 & 0.894 & 0.140 & 0.589 \\
\hline & PCR & 94 & & 0.37 & 2.26 & 4.43 & 0.148 & 0.830 & 0.149 & 1.106 \\
\hline & PLS & 95 & & 0.36 & 2.27 & 4.42 & 0.138 & 0.851 & 0.154 & 0.448 \\
\hline \multirow{3}{*}{$\mathrm{P}_{2} \mathrm{O}_{5}$} & MPLS & 95 & \multirow[t]{3}{*}{1.18} & 0.13 & 0.80 & 1.57 & 0.084 & 0.563 & 0.103 & 1.697 \\
\hline & PCR & 93 & & 0.13 & 0.80 & 1.57 & 0.112 & 0.144 & 0.113 & 0.237 \\
\hline & PLS & 95 & & 0.13 & 0.80 & 1.57 & 0.086 & 0.538 & 0.104 & 1.126 \\
\hline \multirow{3}{*}{$P$} & MPLS & 95 & \multirow[t]{3}{*}{0.52} & 0.05 & 0.35 & 0.68 & 0.036 & 0.554 & 0.044 & 1.056 \\
\hline & PCR & 92 & & 0.05 & 0.35 & 0.68 & 0.045 & 0.168 & 0.046 & 0.102 \\
\hline & PLS & 93 & & 0.05 & 0.36 & 0.67 & 0.035 & 0.534 & 0.042 & 0.408 \\
\hline \multirow{3}{*}{$\mathrm{K}_{2} \mathrm{O}$} & MPLS & 90 & \multirow[t]{3}{*}{1.70} & 0.14 & 1.28 & 2.12 & 0.093 & 0.567 & 0.126 & 4.113 \\
\hline & PCR & 91 & & 0.14 & 1.28 & 2.12 & 0.137 & 0.040 & 0.139 & 1.106 \\
\hline & PLS & 90 & & 0.14 & 1.28 & 2.12 & 0.103 & 0.462 & 0.132 & 3.957 \\
\hline \multirow{3}{*}{ K } & MPLS & 90 & \multirow[t]{3}{*}{1.41} & 0.11 & 1.06 & 1.76 & 0.077 & 0.566 & 0.105 & 3.469 \\
\hline & PCR & 91 & & 0.11 & 1.06 & 1.76 & 0.115 & 0.043 & 0.116 & 3.108 \\
\hline & PLS & 90 & & 0.11 & 1.06 & 1.76 & 0.085 & 0.467 & 0.111 & 3.305 \\
\hline \multirow{3}{*}{$\mathrm{Ca}$} & MPLS & 92 & \multirow[t]{3}{*}{0.35} & 0.07 & 0.11 & 0.58 & 0.074 & 0.105 & 0.075 & 4.187 \\
\hline & PCR & 92 & & 0.07 & 0.11 & 0.58 & 0.074 & 0.122 & 0.075 & 4.189 \\
\hline & PLS & 92 & & 0.07 & 0.11 & 0.58 & 0.075 & 0.067 & 0.076 & 4.187 \\
\hline \multirow{3}{*}{$\mathrm{Mg}$} & MPLS & 92 & \multirow[t]{3}{*}{0.18} & 0.02 & 0.12 & 0.24 & 0.019 & 0.056 & 0.019 & 1.086 \\
\hline & PCR & 93 & & 0.02 & 0.12 & 0.24 & 0.019 & 0.186 & 0.019 & 1.088 \\
\hline & PLS & 92 & & 0.02 & 0.12 & 0.24 & 0.018 & 0.177 & 0.019 & 1.088 \\
\hline \multirow{3}{*}{ PA } & MPLS & 95 & \multirow[t]{3}{*}{0.65} & 0.14 & 0.22 & 1.065 & 0.12 & 0.24 & 0.12 & 0.14 \\
\hline & PCR & 95 & & 0.14 & 0.22 & 1.065 & 0.13 & 0.12 & 0.13 & 0.25 \\
\hline & PLS & 93 & & 0.13 & 0.25 & 1.053 & 0.12 & 0.12 & 0.12 & 0.22 \\
\hline
\end{tabular}

Chem. - chemical parameter; $n$ - number of samples; SD - standard deviation; Mean - mean value; DM - dry matter; Max - maximum value; Min - minimum value; SEC - standard error of calibration; RSO - coefficient of correlation; SECV - standard error of cross validation; SEP - standard error of prediction; PA - phytic acid; MPLS - modified partial least squares regression; PLS - partial least square regression; PCR - principal component regression analysis

Elem. - kemijski parametar; $n$ - broj uzoraka; SD - standardna devijacija; Prosjek - prosječna vrijednost; ST - suha tvar; Max - najveća vrijednost; Min - najmanja vrijednost; SEC - standardna greška kalibracije; RSO - koeficijent korelacije; SECV - standardna greška unakrsne validacije; SEP - standardna greška procjene; PA fitinska kiselina; MPLS - modificirana metoda najmanjih kvadrata; PLS - metoda najmanjih kvadrata; PCR - metoda regresije osnovne komponente

Previous study by Malley et al. (2004) has reported a NIRS equations model excellent for screening purposes if the $R^{2}>0.95$, successful if $R^{2}=0.9-0.95$ and the inadequate if $R^{2}<0.7$.

Based on the above classifications, no element in this research fits excellent in the developed calibration model. Statistics of models developed for microelements prediction in common bean samples by MPLS, PLS and PCR method are presented in Table 3.
According to interpretation of NIR model developed for routine analysis (Williams et al., 1996; Shenk et al., 2001), poor correlation models for microelements were developed for Fe by PLS, Zn by MPLS and for Mn by PCR. Furthermore, models usable for rough sample screening were developed for Mn by MPLS and by PLS.

The coefficients of determination $\left(R^{2}\right)$ obtained in this work (Table 3 ) for the different microelements differ in comparison with those reported by other authors in 
forages and legumes for Fe $\left(R^{2}=0.74\right), Z n\left(R^{2}=0.72\right)$, $\mathrm{K}\left(\mathrm{R}^{2}=0.82\right), \mathrm{Mn}\left(\mathrm{R}^{2}=0.74\right)$ and Ca $\left(\mathrm{R}^{2}=0.75\right)$ (Clark et al., 1989; Vazquez De Aldana et al., 1995; Font et al., 2002). Only results for Mn by PLS $\left(R^{2}=0.69\right)$ were close to those reported by previous authors while others were of much lower suitability for rapid NIR analysis.

MPLS regression was employed to reduce the spectral information of the samples used. At first, a much smaller number of new orthogonal variables was created presenting the original data and being essential in predicting sample properties later on.

The basic statistic parameters compared in the assessment of the regressions equations developed were the coefficient of multiple determination $\left(R^{2}\right)$ and the standard error of calibration (SEC) of the calibration data set to the standard error of prediction (SEP) in the external validation set. A variety of spectral pretreatments were evaluated including first derivative (1 Der), second derivative (2 Der), MSC, SNV and their combinations. With the exception of the external validation set for the first derivative pretreatment, all of the calibrations in Table 2 showed similar $\mathrm{R}^{2}$ and similar SEC as well as SEP values, with different methods applied suggesting that the leave-one-out cross-validation fit applied regressions. The MPLS regression statistics for the external validation data using a first derivative pretreatment suggested this model as the most accurate.

Table 3. Prediction of microelements in common bean samples by modified partial least squares (MPLS) regression, partial least square (PLS) regression and principal component regression (PCR) analysis.

Tablica 1. Procjena količine mikroelemenata u uzorcima graha korištenjem modificirane metode najmanjih kvadrata (MPLS), metode najmanjih kvadrata (PLS) i metode regresije osnovne komponente (PCR).

\begin{tabular}{|c|c|c|c|c|c|c|c|c|c|c|}
\hline $\begin{array}{l}\text { Chem. } \\
\text { Elem. }\end{array}$ & $\begin{array}{l}\text { Method } \\
\text { Metoda }\end{array}$ & $\mathrm{n}$ & $\begin{array}{c}\text { Mean } \\
\% \text { in DM } \\
\text { Prosjek } \\
\% \text { u ST }\end{array}$ & SD & $\begin{array}{c}\text { Min } \\
\% \text { in DM } \\
\text { Min } \\
\% \text { u ST }\end{array}$ & $\begin{array}{c}\text { Max } \\
\% \text { in DM } \\
\text { Max } \\
\% \text { u ST }\end{array}$ & SEC & RSO & SECV & SEP \\
\hline \multirow{3}{*}{$\mathrm{Fe}$} & MPLS & 95 & \multirow{3}{*}{71.75} & 91.14 & 44.32 & 99.17 & 8.95 & 0.04 & 9.09 & 1.087 \\
\hline & PCR & 92 & & 91.14 & 44.32 & 99.17 & 7.55 & 0.27 & 7.96 & 32.78 \\
\hline & PLS & 94 & & 91.14 & 44.55 & 99.84 & 7.20 & 0.39 & 8.29 & 14.05 \\
\hline \multirow{3}{*}{$\mathrm{Zn}$} & MPLS & 93 & \multirow{3}{*}{26.75} & 3.35 & 16.68 & 36.81 & 2.74 & 0.33 & 3.10 & 9.83 \\
\hline & PCR & 93 & & 3.35 & 16.68 & 36.81 & 2.94 & 0.23 & 3.13 & 16.53 \\
\hline & PLS & 93 & & 3.35 & 16.68 & 36.81 & 2.77 & 0.31 & 3.12 & 15.55 \\
\hline \multirow{3}{*}{$\mathrm{Mn}$} & MPLS & 94 & \multirow{3}{*}{16.17} & 2.30 & 9.26 & 23.08 & 1.39 & 0.63 & 1.65 & 26.67 \\
\hline & PCR & 94 & & 2.30 & 9.26 & 23.08 & 1.67 & 0.47 & 1.73 & 3.07 \\
\hline & PLS & 92 & & 2.30 & 9.38 & 22.95 & 1.26 & 0.69 & 1.42 & 4.87 \\
\hline
\end{tabular}

Chem. - chemical parameter; $\mathrm{n}$ - number of samples; SD - standard deviation; Mean - mean value; DM - dry matter; Max - maximum value; Min - minimum value SEC - standard error of calibration; RSQ - coefficient of correlation; SECV - standard error of cross validation; MPLS - modified partial least squares regression; PLS - partial least square regression; PCR - principal component regression analysis

Elem. - kemijski parametar; $n$ - broj uzoraka; SD - standardna devijacija; Prosjek - prosječna vrijednost; ST - suha tvar; Max - najveća vrijednost; Min - najmanja vrijednost; SEC - standardna greška kalibracije; RSO - koeficijent korelacije; SECV - standardna greška unakrsne validacije; SEP - standardna greška procjene; MPLS - modificirana metoda najmanjih kvadrata; PLS - metoda najmanjih kvadrata; PCR - metoda regresije osnovne komponente

The results obtained by the conventional methods showed the variability in composition. It was expected as influenced by the soil, plant age, climatic factors, and genetic characteristics (Rachwal et al., 2002; Reissmann and Carneiro, 2004). In this research, only genotype affected the element composition while the growth conditions were the same for all the accessions. Moreover, the used common bean accessions were collected all over Croatia, showing great genetic diversity reported by Carović-Stanko et al. (2017).
Figure 2 shows the comparison of laboratory determined (LAB) and NIR predicted data for N and PA content (\% DM based) by PLS method.

Considering SEP and SEC coefficients, the model developed by PLS for N extended 0.448 and 0.449 , respectively while the reliability for PA was much lower ( 0.12 and 0.22 , respectively).

Figure 3 shows the comparison of laboratory determined (LAB) and NIR predicted data for Fe and Mn content (\% DM based). 

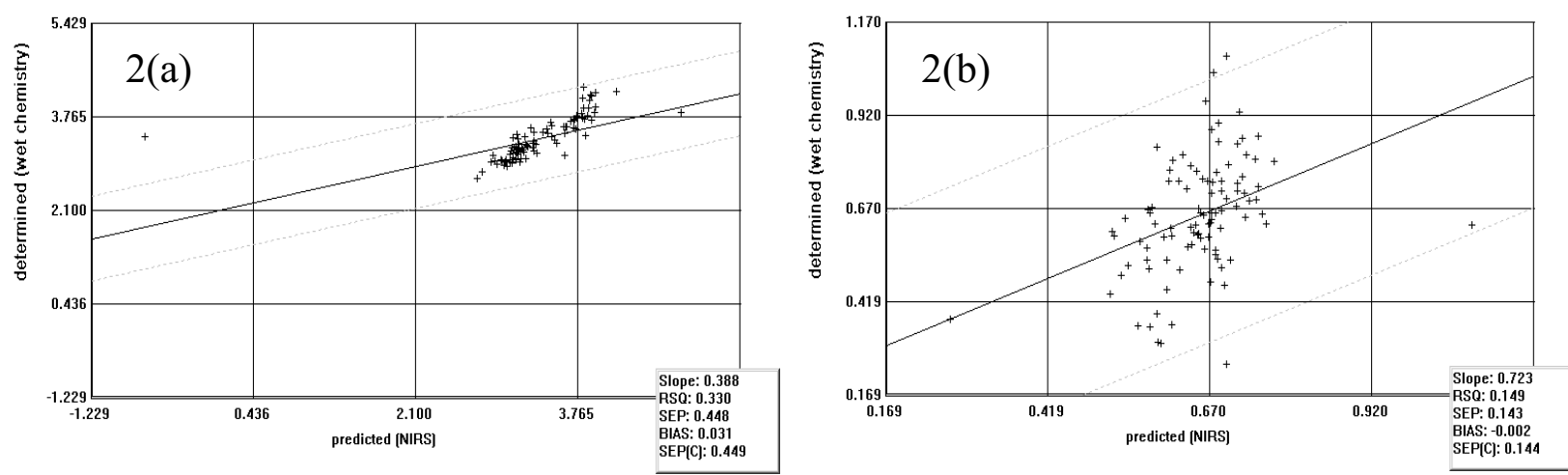

Figure 2. The relationship between partial least square data calculated from near infrared (NIR) spectral data and the measured chemical (LAB) data for (a) $\mathbf{N}$ content (\% DM based) and (b) PA content (\% DM based) investigated by PLS method.

Slika 2. Korelacija između spektralnih podataka (NIRS) procijenjenih korištenjem metode najmanjih kvadrata (PLS) $i$ vrijednosti utvrđenih mokrom kemijom (LAB) za (a) sadržaj N (bazirano na \% ST) i (b) sadržaj PA (bazirano na \% ST).
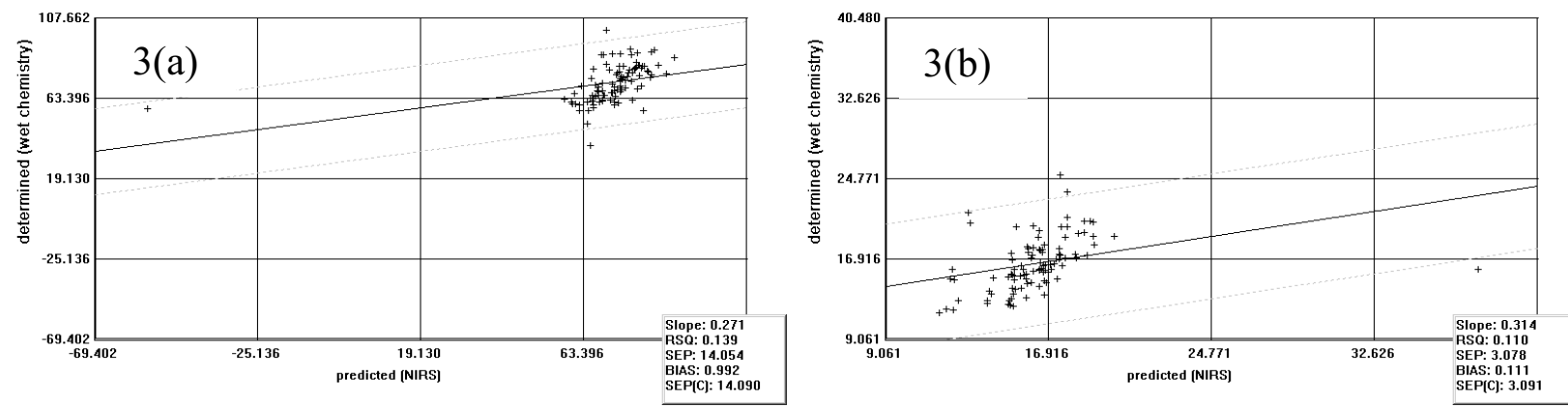

Figure 3. The relationship between principal component regression/PCR calculated from near infrared (NIR) spectral data and the measured chemical (LAB) data for (a) Fe (\% DM based) and (b) Mn (\% DM based).

Slika 3. Korelacija između spektralnih podataka (NIRS) procijenjenih korištenjem metode regresije osnovne komponente (PCR) i vrijednosti utvrđenih mokrom kemijom (LAB) za (a) Fe (bazirano na \% ST) i (b) Mn (bazirano na \% ST).

The results obtained are partly supported by the previous research (Büning-Pfaue, 2003; Cen and He, 2007) reporting poorer calibration models developed for microelements than for macroelements. The reason is likely to be the lower signal to noise ratio thus higher influence of particle size than component concentration on spectral variation in calibrations developed for microelements than for macroelements prediction (Shenk et al., 2001).

According to the described, the results achieved partly confirm hypothesis of the present research. The greatest disadvantage in NIR spectroscopy in comparison with wet chemistry is a weak sensitivity to components represented in small quantities (BüningPfaue, 2003). Thus, it significantly decreases when the concentration of the component to be predicted is below $0.1 \%$ (Cen and He, 2007). According to the mentioned, the poor correlation models were developed for mineral constituents represented in minor quantities (for $\mathrm{K}, \mathrm{K}_{2} \mathrm{O}$, $\mathrm{Fe}, \mathrm{Zn}, \mathrm{Mn}$ ) while models usable for rough sample screening were developed for $\mathrm{P}_{2} \mathrm{O}_{5}, \mathrm{P}, \mathrm{K}_{2} \mathrm{O}, \mathrm{K}$ and $\mathrm{Mn}$.
In this research, the model reliability followed the concentration level, thus the higher element concentration resulted in higher reliability of the model with the greatest developed for $\mathrm{N}$ followed by $\mathrm{K}_{2} \mathrm{O}, \mathrm{K}$ and $\mathrm{P}_{2} \mathrm{O}_{5}$. The exception was a low Mn concentration (only $16.37 \mathrm{mg}$ $\mathrm{kg}^{-1} \mathrm{DM}$ ) but a higher confidence model than expected $\left(R^{2}=0.69\right.$ by PLS) was developed.

One of the NIR spectroscopy advantages compared to classical chemical methods are quick results of analysis. This support raising crop quality and prevent adulteration in leguminous crops (Font et al., 2006; Wang et al., 2006).

By the previous research, the developed model only for $N\left(R^{2}=0.83-0.89\right.$; $\left.S E P=0.55\right)$, fits the suitability for parameter prediction by NIR spectroscopy. The NIR spectroscopy for other minerals was of lower suitability than the previously reported (calculated $R^{2}$ were 0.73 , $0.85,0.90,0.80$, and 0.81 for $\mathrm{P}, \mathrm{Mg}, \mathrm{Fe}, \mathrm{Zn}, \mathrm{Mn}$ respectively, while that of SEP were 0.86, 0.32, 6.48, 5.86, and 5.72 for $\mathrm{P}, \mathrm{Mg}$, Fe, Zn, Mn respectively (Font et al., 2006; Wang et al., 2006). 
Hyperspectral analysis by MPLS resulted in the highest accuracy for the estimation of most elements evaluated. However, $\mathrm{Ca}$ and $\mathrm{Mg}$, which were more accurate by PCR or Fe and Mn which were of higher accuracy by PLS than MPLS regression were applied.

\section{CONCLUSION}

Results of this research support the idea that NIRS technology has a great potential for low cost, non-destructive analysis of mineral content in common bean samples. This technique could be used for quality control as well as for the breeding programs of common bean genotypes.

From the data obtained, NIRS can be used for screening purposes of total $\mathrm{N}$. The poor correlation models were developed for $\mathrm{K}_{1} \mathrm{~K}_{2} \mathrm{O}, \mathrm{Fe}$ and $\mathrm{Zn}$ while models usable for rough sample screening were developed for $\mathrm{P}_{2} \mathrm{O}_{5}, \mathrm{P}$ and $\mathrm{Mn}$.

The MPLS regression statistics is suggested as the most accurate model for predicting mineral components in bean samples compared with PLS and PCR methods applied.

A wider set of common bean samples is recommended for developing the calibration equations for the prediction of macro and microelements in common bean samples as the sensitivity of NIR greatly decreases when the element concentration is low.

\section{ACKNOWLEDGEMENT}

This work has been supported by Croatian Science Foundation under the project UIP-11-2013-3290 Genetic basis of bioactive nutrient content in Croatian common bean landraces (BeanQual).

\section{REFERENCES}

1. AOAC (1995). Official Method of Analysis of AOAC International. 16th Edition, Vol. I. Arlington, USA.

2. Büning-Pfaue, H. (2003). Analysis of water in food by near infrared spectroscopy. Food Chemistry, 82(1), 107115. https://doi.org/10.1016/S0308-8146(02)00583-6

3. Carović-Stanko, K., Liber, Z., Vidak, M., Barešić, A., Grdiša, M., Lazarević, B., \& Šatović, Z. (2017). Genetic diversity of Croatian common bean landraces. Frontiers in Plant Science, 8, 604. https://doi.org/10.3389/fpls.2017.00604

4. Cen, H., \& He, Y. (2007). Theory and application of near infrared reflectance spectroscopy in determination of food quality. Trends in Food Science \& Technology, 18(2), 72-83. https://doi.org/10.1016/j.tifs.2006.09.003

5. Clark, D. H., Cary, E. E., \& Mayland, H. F. (1989). Analysis of trace elements in forages by near infrared reflectance spectroscopy. Agronomy Journal, 81(1), 91-95. https:// doi.org10.2134/agronj1989.00021962008100010016x

6. Davies, A.M.C., \& Williams, P. (1996). Near infrared spectroscopy: the future waves. Proceedings of the Seventh
International Conference on Near Infrared Spectroscopy. NIR Publications, Chichester, West Sussex, UK.

7. FAO - Food and Agriculture Organization of United nations. FAOSTAT - CROPS. Available online: https:// www.fao.org/faostat/en/\#data/QC (accessed on $5 \mathrm{Mar}$ 2019).

8. Font, R., del Río-Celestino, M., \& de Haro-Bailón, A. (2006). The use of near-infrared spectroscopy (NIRS) in the study of seed quality components in plant breeding programs. Industrial Crops and Products, 24(3), 307313. https://doi.org/10.1016/j.indcrop.2006.06.012

9. Font, R., Del Río, M., \& De Haro, A. (2002). Use of near infrared spectroscopy to evaluate heavy metal content in Brassica juncea cultivated on the polluted soils of the Guadiamar River area. Fresenius environmental bulletin, 11(10), 777-781.

10. Ganesan, K., \& Xu, B. (2017). Polyphenol-rich dry common beans (Phaseolus vulgaris L.) and their health benefits. International journal of molecular sciences, 18(11), 2331. https://doi.org/10.3390/ijms18112331

11. Haughey, S. A., Graham, S. F., Cancouët, E., \& Elliott, C. T. (2013). The application of near-infrared reflectance spectroscopy (NIRS) to detect melamine adulteration of soya bean meal. Food Chemistry, 136(3-4), 1557-1561. https://doi.org/10.1016/j.foodchem.2012.01.068

12. HRN ISO 11261:2004 - Soil quality - Determination of total nitrogen - Modified Kjeldahl method (ISO 11261:1995).

13. ISI (1999). Infrasoft International, LLC (ISI) Windows Near Infrared Software, WinISI II, Version 1.02A. p. 192. Foss NIRSystems, Silver Spring, Maryland, USA

14. Kaliramesh, S., Chelladurai, V., Jayas, D. S., Alagusundaram, K., White, N. D. G., \& Fields, P. G. (2013). Detection of infestation by Callosobruchus maculatus in mung bean using near-infrared hyperspectral imaging. Journal of Stored Products Research, 52, 107 111. https://doi.org/10.1016/j.jspr.2012.12.005

15. Kirk, R.E. (1995). Experimental design: Procedures for the behavioral sciences (3rd ed.). Pacific Grove, CA: Brooks/Cole.

16. Lešić, R., Borošić, J., Buturac, I., Herak Ćustić, M., Poljak, M., \& Romić, D. (2016). Povrćarstvo. Čakovec: Zrinski d.d.

17. Malley, D., Martin, P.D., \& Ben-Dor, E. (2004). Application in analysis of soils. In: Roberts CA, Workman $\mathrm{Jr} J$ Reeves JB, editors. Near infrared spectroscopy in agriculture. Madison: American Society of Agronomy, Crop Science Society of America, and Soil Science Society of America; pp. 729-784.

18. Nicolai, B. M., Beullens, K., Bobelyn, E., Peirs, A. Saeys, W., Theron, K. I., \& Lammertyn, J. (2007). Nondestructive measurement of fruit and vegetable quality by means of NIR spectroscopy: A review. Postharvest biology and technology, 46(2), 99-118. https://doi.org/10.1016/j.postharvbio.2007.06.024

19. Osborne, B. G. (2006). Applications of near infrared spectroscopy in quality screening of early-generation material in cereal breeding programmes. Journal of near infrared spectroscopy, 14(2), 93-101. https://doi.org/10.1255/jnirs.595

20. Petry, N., Boy, E., Wirth, J. P., \& Hurrell, R. F. (2015). Review: The potential of the common bean (Phaseolus 
vulgaris) as a vehicle for iron biofortification. Nutrients 7, 1144-1173. https://doi.org/10.3390/nu7021144.

21. Rachwal, M. F. G., Coelho, G. C., Dedecek, R. A., Curcio, G. R., \& Schenkel, E. P. (2002). Influence of light on leaf weight and content of macronutrients, total phenols, caffeine and theobromine in yerba mate leaves. Embrapa Florestas. Comunicado técnico. Colombo, Paraná 81, 5.

22. Reissmann, C. B., \& Carneiro, C. (2004). Growth and chemical composition of yerba-mate (llex paraguariensis ST. HIL.), after eight years from liming. Revista Floresta, 34(3), 381-86.

23. Shenk, J., \& Westerhaus, M. (1996). Calibration the ISI way. En "Near Infrared Spectroscopy: The Future Waves". Eds. Davies, AMC e Williams, 198-202.

24. Shenk, J. S., Workman, J. J., \& Westerhaus, M. 0. (2001). Application of NIR spectroscopy to agricultural products. Practical Spectroscopy Series, 27, 419-474.

25. Suárez-Martínez, S. E., Ferriz-Martínez, R. A., CamposVega, R., Elton-Puente, J. E., de la Torre Carbot, K., \& García-Gasca, T. (2016). Bean seeds: leading nutraceutical source for human health. CyTA-Journal of Food, 14(1), 131-137.

https://doi.org/10.1080/19476337.2015.1063548

26. Vajić, B. (1964). Živežne namirnice, određivanje glavnih sastojaka. Sveučilište u Zagrebu, Zagreb, Hrvatska.

27. de Aldana, B. V., Criado, B. G., Ciudad, A. G., \& Corona, M. P. (1995). Estimation of mineral content in natural grasslands by near infrared reflectance spectroscopy. Communications in Soil Science and Plant Analysis, 61910), 1383-1396.

https://doi.org/10.1080/00103629509369379

28. Vranić, M., Bošnjak, K., Glavanović, S., Vinceković, M., Jareš, D., \& Cundić, A. (2016). Prediction of Chemical Composition from Semi-natural Grassland by NIR Spectroscopy. Agriculturae Conspectus Scientificus, 81(1), 35-41. https://hrcak.srce.hr/168586

29. Vranić, M., Pospišil, A., Bošnjak, K., Perčulija, G., Kutnjak, H., Leto, J., \& Sokolović, D. (2012, January). The potential of NIR spectroscopy for crude protein prediction in spelt (Triticum spelta L.). In 47. hrvatski $i 7$. međunarodni simpozij agronoma, 565-569.

30. Wang, L., Lee, F. S., Wang, X., \& He, Y. (2006). Feasibility study of quantifying and discriminating soybean oil adulteration in camellia oils by attenuated total reflectance MIR and fiber optic diffuse reflectance NIR. Food Chemistry, 95(3), 529-536.

https://doi.org/10.1016/j.foodchem.2005.04.015

31. Williams, P. E. S. D. (1996). How do we do it: a brief summary of the methods we use in developing near infrared calibrations En "Near Infrared Spectroscopy: The Future Waves". Eds. Davies, AMC e Williams. 185188.

\section{PROCJENA KOLIČINE MAKRO- I MIKROELEMENATA U HRVATSKIM TRADICIJSKIM KULTIVARIMA GRAHA (Phaseolus vulgaris L.) KORIŠTENJEM SPEKTROSKOPIJE U BLISKOME INFRACRVENOM PODRUČJU (NIRS)}

\section{SAŽETAK}

U ovome je istraživanju korištena spektroskopija u bliskome infracrvenom području (NIRS) za procjenu količine esencijalnih makro- i mikroelemenata u uzorcima najčešće uzgajanih kultivara graha (Phaseolus vulgaris $L$.) u Republici Hrvatskoj. Ukupno 175 uzoraka graha korišteno je za razvoj kalibracije uporabom modificirane metode najmanjih kvadrata (MPLS), metode regresije osnovne komponente (PCR) i metode najmanjih kvadrata (PLS). $S$ obzirom na koeficijent korelacije $\left(R^{2}\right)$, standardnu grešku kalibracije (SEC) $i$ standardnu grešku procjene (SEP), razvijeni kalibracijski modeli su (i) gotovo primjenjivi za procjenu dušika $(N)(0,89 ; 0,12$ i 0,45), (ii) slabo primjenjivi za procjenu željeza (Fe), cinka (Zn), kalijevog oksida $\left(K_{2} \mathrm{O}\right)$ i kalija (K) te (iii) upotrebljivi za fosfor pentoksid $\left(\mathrm{P}_{2} \mathrm{O}_{5}\right)$, fosfor (P), fitinsku kiselinu (PA) i mangan (Mn). Najpouzdaniji kalibracijski modeli razvijeni su korištenjem regresijskoga modela MPLS u usporedbi s kalibracijskim modelima dobivenim korištenjem PLS-a i modelima PCR-a. Zaključeno je da je za procjenu makro- i mikroelemenata spektroskopijom u bliskome infracrvenom području (NIRS) potrebno prikupiti veći broj uzoraka graha širih varijacija istraživanih makro- $i$ mikroelemenata.

Ključne riječi: grah, makroelementi, mikroelementi, minerali, NIRS

(Received on July 12, 2018; accepted on April 15, 2019 - Primljeno 12. srpnja 2018.; prihvaćeno 15. travnja 2019.) 